\title{
horacio, POETA PERENE
}

\author{
Camillo Ferronato \\ Universidade Federal do Paraná
}

\begin{abstract}
RESUMO
Pela profundidade, abrangência e penetraçāo de sua obra, Horácio granjeou admiradores e seguidores até os dias de hoje. Dele pode-se dizer que é um poeta sempre atual, conforme sua profecia. Ensina-nos a aproveitarmos o dia de hoje - "carpe diem" - com moderaçāo, pois o tempo passa rápido. A idéia de morte é uma constante. Proust, na França, deixa filtrar influência horaciana; no Brasil, Manuel Bandeira sobressai-se. Em Portugal, Fernando Pessoa-Ricardo Reis mostra evidencias da filosofia horaciana em suas odes principalmente. Laivos dessa mes$\mathrm{ma}$ corrente filosófico existencialista encontramos em David Mourão-Ferreira. Há muitos elementos de identificaçāo entre Horácio e o cristianismo, máxime quando fala da inutilidade das paixões, da despreocupaçāo pelas coisas passageiras, da busca incessante da paz de espirito. Sua obra corporificou-se como um monumento literário da humanidade.
\end{abstract}

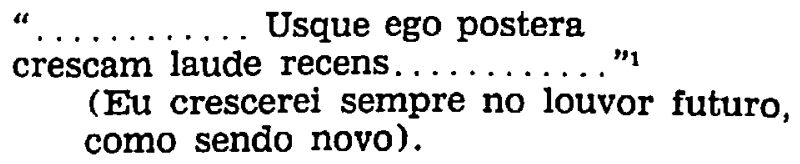

Profeta ou não, essas palavras saíram da pena de HORÁCIO no remotíssimo primeiro século antes de Cristo, mas parece que ontem ainda ele dizia exatamente a mesma coisa. Séculos, milênios passaram-se. Lemos hoje esses mesmos versos em muitos livros didáticos, como se estivéssemos diante da tumba horaciana meditando sobre seu epitáfio.

1 SELLAR. W.Y. The Roman poots of the Augustan age. Horsce and the eleglac poets.

Letras, Curitiba (38) 231-249 - 1989 - UFPR 
Acredito que poucos - provarelmente só os que desconhecem o mérito da questão - ousariam pôr em xeque a veracidade da assertiva de Horácio.

Pela leitura e análise de suas obras, principalmente das Odes, percebemos que o poeta nos fala com as nuances de um contemporâneo. A fugacidade do tempo e a angústia por causa da morte - temas tão antigos quanto o próprio homem, mas tão atuais quanto a própria morte - são uma constante que permeia suas Odes; não deixam de marcar presença em outras obras suas.

Para provar isso logo na entrada deste trabalho, basta dizer que toda a tessitura da Ode I, II - dedicada a sua amiga Leucônoe - envolve o leitor numa atmosfera de indagação, profundamente realística. E Horácio é taxativamente proibitivo quando se trata de querer vislumbrar qualquer circunstância que seja do "post-mortem". Depreende-se um presságio fulminante para quem, porventura, ousasse deso. bedecer a essa advertência:

"Tu ne quaesieris (scire nefas) quem mihi, quemtibi finem di dederint, Leuconoe, nec Babylonios temptaris numeros..." (v. 1-3).

"Não procures saber - é proibido - que fim os deuses destinaram a mim, qual a ti, ó Leucônoe, nem tentes os números babilônicos).

Essa mesma angústia pelo que vem depois da morte, presente na obra horaciana com muita frequiência, atravessou a bartreira de dois mil anos, incrustada no âmago mais profundo de todo ser racional e sensato. Mas o "scire nefas" é proibido saber - na essência faz parte da ciência universal e como tal parece ser aceito, ainda que muitissimas pessoas busquem, por todos os meios, quem ou o que thes diga algo sobre o seu futuro. E se, porventura, esse algo transparece das linhas das māos, dos números ou figuras das cartas ou de quaisquer processos aleatórios - e que näo seja do in. teresse delas - pronto, perdem a "tranquillitas animi" - a tranquiilidade do espírito. Chegam a mudar de residência e mesmo de cidade; evitam sair à noite; fogem dos cruzamentos, etc. Em sintese, as superstiçōes arraigadas nelas fazem-nas pressentirem fatalidades desmoronando sobre suas cabeças.

Para Horácio, morte e tempo são temas inseparáveis. Em "ultima linea rerum" - última linha das coisas - (Epist. $I, 16,79$ ), ele dá a entender que é a morte que dá ao homem a angústia do tempo. $\mathrm{E}$ a morte que tira do tempo a alenta- 
dora idéia cíclica da natureza para estendê-lo à breve linha da vida humana.

O termo "brevis" é de alta frequiência nele. Cito uma passagem altamente significativa a esse respeito:
"Huc vina et unguenta et nimium brevis
flores amoenas ferre iube rosae, dum res et aetas et Sororum
fila trium patiuntur atra". (Odes II,3.v.13-16).
(Manda trazer para cá os vinhos e os unguientos e as excessivamente breves flores da amena rosa, enquanto as coisas e o tempo e os negros fios das três irmãs permitem).

O polissindeto representado pela presença de 4 "et" sugere uma idéia de rapidez, de acúmulo de informações da frase, criando um paralelismo rítmico. E exatamente para manifestar a mensagem de que é grande a quantia de condiçōes indispensáveis para que se tenha realmente uma vida feliz, usufruindo-as nos momentos muito breves quando elas se encontram todas reunidas. Dependemos das circunstân. cias - "res" - , do tempo e do destino, costurado pelas três irmãs, as Parcas. Estas tecem com fios negros, simbolizando as sombras, pois que a meada, passando por entre os dedos, prepara $o$ instante da morte. Horácio não diz simplesmente "brevis"; escreve "nimium brevis". $O$ advérbio de intensidade semanticamente introduz um detalhe de profunda relevância, denotando um superlativo absoluto. Se curtirmos a vida com toda a intensidade, estaremos fazendo o mesmo que regando rosas para que não murchem. São de muito breve duração as flores das rosas, simbolizando o contraste das alegrias do canto e da vida em relação com a infinitude da outra vida, além-túmulo.

Os enginamentos de Horácio envolvem um conteúdo de grande profundidade filosófica. Nem por isso esquecem o pragmatismo do dia-a-dia: Năo devemos nos deixar abater pelos contratempos, nem nos inebriar pela fortuna. Mas vem o pensamento positivo: Devemos gozar os bens presentes por aquilo que eles são em si mesmos, não ignorando que eles são precários. Quer sejamos ricos, quer, pobres, um mesmo fim nos espera igualmente. Os versos finais são eloquientes por si mesmos:

\footnotetext{
"omnes eodem cogimur, omnium versatur urna serius ocilis sors exitura et nos in aeternum exilium impositura cumbae" (Odes, II, e, v. 25-28)
} 
(todos somos impelides para o mesmo lugar; a sorte de todos, devendo sair mais cedo ou mais tarde e tendo de colocar-nos na barca para o exilio eterno, resolve-se na urna).

Caronte leva a todos em sua barca, indistintamente. Se fosse possivel montar aqui uma polifonia, ela seria feita de sons longos e soturnos, criando um "rallentando" muito elo. quiente que acompanharia a idéia de infinito contida na extensão das próprias palavras: "aeternum exilium impositura cumbae". E o eco ouve-se ao longe: "cumbae... cumbae... cumbae..."

A dicotomia tempo/morte caracteriza a preocupação fun. damental de Horácio numa fase de sua produção literária. Na Ode II, 14 torna-se explicita essa idéia de dualidade irrefutável. A ode lembra-nos que a morte é inevitável, que a própria prudência não nos livra dela; seu dia chega rapidamente. Então é necessário dar adeus aos bens, ainda que os mais doces e legítimos. $E$ possivel que nossas inúteis economias sejam dissipadas por um herdeiro indiferente e perdulário. Assim fala:

"Eheu fugaces, Postume, Postume, labuntur anni, nec pietas moram

Rugis et instanti senectae

Adferet indomitaeque morti". (Odes, II, 14, v. 1-4) (Ai! Póstumo, Póstumo! Os anos correm velozes; e a piedade năo trará demora para as rugas e para a velhice que chega e para a indómita morte).

A repetição do vocativo, que corresponde a uma sensa. ção de aborrecimento e de desalento, lembra um apelo renovado de alguém que se encontra em situação de anguistia. Nem mesmo o dever para com os deuses - "pietas" - que Cícero chama de "justitia adversum deos", fará o homem se afastar da linha que o impele para a velhice.

Os termos "fugaces", "labuntur" e "instanti" são palavras-chave nesses versos; eles trazem conotação de procura do tempo, de busca do tempo, como se estivéssemos sempre ao encalço dele, exatamente porque o sabemos escorregadio. Nossos dicionários registram, para esse termo, o valor de "rápido, que foge rapidamente". Etimologicamente, contudo, ele lembra, conotado negativamente, o soldado que foge de seu posto de combate. Ligar o termo a morte, portanto, significa fazer dele como se incorporasse traidores que nos abandonam de repente, num valor metafórico muito signi- 
ficativo. Associa-se a ele "labuntur", lexema que lembra um deslizar furtivo e silencioso.

Enquanto isso, a velhice é "instanti": ela fica insistindo à porta de nossa vida, ameaçadora, iminente.

O próprio vocativo "Postume" carrega em si um sabor de morte. Tudo somado dá um dinamismo sem igual que desemboca na locuçāo "indomitaeque morti". Para E. MINKOWSKI, Horácio faz parte do grupo de pessoas que "vivem mais sob os auspícios do tempo que passa e da morte que se avizinha do que do tempo que progride e que fazemos progredir em nós":

No caso específico de Horácio, a angústia do tempo, o senso da precariedade das coisas revelam nele uma psique insegura, cujas raízes podem ser buscadas na falta de um carinho materno na sua infância. Tal inferência pode ser tirada do seu silêncio quase total a respeito de sua māe, embora faça muitas referências a seu pai. Associada a essa suposição está a de que a derrota em Filipos, com a consequiente morte da idéia republicana, teria transtornado a Horácio. Os bens paternos lhe foram confiscados, e ele chegou a passar por dificuldades financeiras.

Fica bem clara a idéia do "carpe diem" horaciano em toda a extensão do raciocínio desenvolvido até aqui. Se o tempo passa célere, e a vida é curta, é preciso aproveitá-la, degustá-la em todos os momentos. A palavra "labuntur" poderíamos associar ainda a idéia de líquido. Horácio explora, de fato, esse campo semântico para conotar a transitoriedade do tempo, que é etéreo e se dilui, como os líquidos. Patenteiase, assim, seu estoicismo e seu epicurismo. Nada no mundo pode dar-nos segurança. Ricos, pobres, poderosos e fracos, estamos todos na mesma barca (de Caronte). Ele lembra muito bem a Lucrécio ("De Rerum Natura") e seu epicurismo.Este fala que os grandes homens também morrem (III, 1.037). Lembra também a Homero, quando aborda o papel dos deuses no destino dos homens, mas com uma diferença fundamental: Na Odisséia, os deuses interferem pró ou contra os homens; em Horácio, não. Embora mencione constantemente os deuses, é difícil dizer o que realmente significam estes para Horácio. Ele serve-se da mitologia para expressar motivos legendários, bem como para descrever sucessos históricos. O motivo puramente literário (Ode II, 7) mostra com bastante clareza que não cria realmente que Hermes lhe tivesse salvado a vida na batalha no estilo dos deuses em Homero.

2 MINkOWSkI. F. Il tempo vlssuto. In: ORAzIO Flacco, QuInto, Odi Epodi. Mulano: BUR. 1085. D. 11. 
Horácio utiliza muito vocabulário ou expressōes populares em suas obras, certamente para dar um caráter de maior identificaçāo com a realidade e ser mais acessivel a todas as camadas da sociedade romana. No poema em análise, seus adjetivos caracterizam a transitoriedade ("fugaces, indomitae, illacrimabilem, amplum, tristi, inopes, cruento, fractis, raucis, languido, nocentem, ater, longi, infame, invisas, brevem, superbo" etc.), enquanto os substantivos, o concreto ("anni, pietas, moram, rugis, senectae, morti, dies, amice, tauris, unda, terrae, reges, coloni, Marte, autumnos, laboris, tellus, domus, uxor" etc.). Usa a palavra "cupressos" (ciprestes) querendo conotar a própria morte, pois essa árvore era dedicada a Plutāo. Os antigos a plantavam junto aos túmulos. Como sinal de luto de uma familia, eles colocavam galhos de ciprestes diante das portas das casas. Pode-se dizer que hoje em dia ainda essa árvore é símbolo intimamente ligado à idéia de morte, de luto, de tristeza. Para carregar mais ainda a mensagem, Horácio "decora" a planta com um atributo semanticamente negativo: "invisas" (tristes, desagradáveis, odiosas, odiadas). Aparece um adjetivo com valor onomatopaico agradável: "placens" (que agrada); aliás, morfologicamente, trata-se de um participio presente, com função sintática de adjunto adnominal. Logo, atribui qualidade, leva à abstração: ela, a esposa, agrada não em geral, mas a seu marido.

O poeta apresenta uma fatídica realidade: "Linquenda tellus et domus et placens uxor..." Tudo deve ser deixado: terra, casa e esposa. Por quê? Porque aguarda a única coisa real: a morte. Como ironia epicurista, arremata: "absumet heres... dignior": e um herdeiro mais digno arrancará, esgotará a herança. Com o prefixo "ab" como início do verbo, vem-nos a idéia de rapto, de desaparecimento por inteiro. Para trás ficou o "brevem dominum": o senhor por pouco tempo, o senhor efêmero, dentro de uma visão ainda epicurista. E, ironicamente, fecha a ode com um "gran finale":

"......... et mero

Tinget pavimentum superbis

Pontificum potiore cenis". (Odes, II, 14, v. 27-28).

(E molhará o pavimento com um vinho mais digno de soberbas ceias dos pontífices).

Assim fica a lição: não adianta acumular riquezas. Vem a morte, que nos leva, e os herdeiros locupletar-se-āo com a herança deixada. $\mathrm{E}$ a triste "condition humaine".

A semente horaciana da dicotomia tempo/morte e suas implicâncias germinou, e muito, pelos séculos afora. Deu 
frutos na França, no início deste século, com Marcel Proust, "A la Recherche du Temps Perdu". A idéia de que não devemos perder tempo, pois a vida é breve e a morte nos espreita, foi também assimilada por esse grande escritor francês, que, por sua yez, teve um raio de influência de extraordinária penetração. Proust considera objeto da obra literária a descriçāo do universo refletido e deformado pelo espírito. A vida, tal qual se escoa, não é mais que tempo perdido; o tempo só pode realmente ser achado novamente, e salvo, sob o aspecto da eternidade, que é também o da arte. Para Proust, a realidade permanece indefinível $e$ inapreensível. Muda constantemente já que o fluxo do tempo altera nāo apenas a sua própria perspectiva, mas também a natureza daquilo que é percebido. Ele reconhece que a realidade não é uma coisa externa, mas algo que se armazena nas camadas profundas da memória inconsciente do homem. Ai permanece, preservada das mudanças do tempo, mas torna-se acessivel apenas raramente, em momentos privilegiados. Os artistas podem revelar a realidade à humanidade porque sua sensibilidade os capacita a revolverem profundomente sua memória . inconsciente.

Proust descreve todos os niveis da sociedade francesa, especialmente o da aristocracia e o da classe média rica, e também explora o desenvolvimento da carreira de um escritor.

Portanto, há muita coisa em comum entre Horácio e Proust. Este, após procurar o tempo perdido, parece encontrá-lo, e nos apresenta "Le Temps Retrouve".

No âmago do problema horaciano e proustiano está o homem diante de seus valores existenciais. Em Horácio existe uma grandeza ética na qual ele parece atingir o nivel de Lucrécio, na sua concepção da relação do homem com seu poder pessoal de executar compromissos humanos. Sua filosofia é baseada mais na observação da vida do que em qualquer concepção especulativa. Mas, como Lucrécio sob a concepção da Natureza declara sua fé na onipotência da lei no universo, e Virgilio na personificação dos "Fados" implica sua fé nos firmes desígnios da Providência, o pensamento sempre presente na mente de Horácio é a incerteza nos assuntos humanos, que ele personifica sob o nome de "Fortuna", e o limite imposto em todo o esforço e prazer pela inevitável certeza da morte, que ele personifica como "Necessidade". O aspecto de ironia em assuntos humanos, de que Lucrécio fala como a "vis abdita quaedam" (v. 1233), apresenta-se para a imaginação como um poder pessoal: 
"Fortuna saevo laeta negotio" (Odes, III, 29,49). (A Fortuna alegre com oficio cruel).

Duas lições tira Horácio desse aspecto da vida: a necessidade da absoluta dependência de cada homem de si mesmo, e a necessidade de limitar seus desejos. Ser senhor de si mesmo e encontrar felicidade nos prazeres simples são as lições que Horácio extrai de sua filosofia.

Na passagem já citada acima: "Linquenda tellus et do. mus e placens uxor" encontramos uma calma resignação por parte do poeta. Em Lucrécio, deparamo-nos com uma austera consolaçāo. $O$ temor da morte é posto de lado pelo poder da mente, pelo senso de reconciliação com a lei universal da natureza. Horácio tira do pensamento sobre a morte a lição de intensificar o prazer do presente. $E$ seu "carpe diem".

$\mathrm{Na}$ galeria dos que, por coincidència ou intencionalmente, têm a mesma linha de pensamento de Horácio quanto ao aspecto existencial vida/morte, vale citar Manuel Bandeira, entre os nossos. Seu poema faz pensar a qualquer individuo, mesmo que a contragosto:

\section{Consoada}

Quando a indesejada das gentes chegar

Nāo sei se dura ou caroável

Talvez eu tenha medo

Talvez sorria, ou diga:

- Aló, iniludivel.

O meu dia foi bom, pode a noite descer

(A noite com seus sortilégios)

Encontrará lavrado o campo, a casa limpa

A mesa posta,

E cada coisa em seu lugar.

5 patente a presença da idéla de morte no poema de Bandeira. E não só de morte como um elemento da abstra. ção, mas como algo concreto, interlocutor no processo dialógico. Tão concreto que chega a assustar. Apelando para a metalinguagem, percebe-se que o espectro da morte sibila como numa orquestra digna de um "Requiem" de Berlioz. Ao contrário dos compositores em geral, Manuel Bandeira parte de uma estonteante "ouverture" para um final "rallentando", num autêntico "requiem".

Bandeira é muito coerente em sua linha filosófica: Se o "dia foi bom, pode a noite descer", embora o além da linha divisória seja uma grande incógnita: Será a noite-morte uma feiticeira muito maléfica? Para onde me conduzirāo 
suas artimanhas?. . Ele transmite a "tranquillitas animi" de um eremita que se preparou a vida inteira para morrer pacificamente. Não se trata, conseüentemente, de um simples conformismo com uma fatalidade iniludivel. Existe, sim, uma aceitação, uma adesão à realidade humana, ainda que se indagando com S. Paulo: "Ubi est, mors, victoria tua? Ubi est, mors, stimulus tuus?" (I Cor 15,55).

Existem muitos pontos de convergência entre os dois poetas. Do seu retiro longe de Roma, Horácio manda mensagens em código poético para seus concidadãos, onde prega a "tranquillitas animi". $E$ bem verdade que sua moral era voltada para o interior do próprio individuo, sem envolvimento com o outro. O leitor é tentado a imaginar um prenúncio de cristianismo latente em muitas passagens horacianas. Seguindo o raciocínio em análise, contudo, a visão egoísta de sua moral afasta-o da concepção cristã; esta prega, como primeiro e maior mandamento, o amor a Deus e ao próximo, adequado este amor ao amor de si mesmo. Transparece a moral antiga, em Horácio, na qual não havia ligação do indivfduo com o outro. Para ele, tranquiilidade de espirito significa atingir o patamar do autocontrole, da auto-suficiência: na terminologia grega, alcançar a "autárkeia". O poeta não se prende a uma filosofia específica; sua suma ética tende tanto para a "autárkeia" quanto para a liberdade. Não há referências à teologia nem à cosmologia. Daí podemos entender sua instabilidade com relação à ética e à moral. Isso talvez se deva à influência que ele recebeu da diatribe, que só se preocupava dos costumes da época. Tal preocupação era mais característica da diatribe cínica, que se interessava preponderantemente das classes sociais mais baixas, mais humildes. Ela levava a "autárkeia" ao extremo limite.

Nāo se pode esquecer que, para os antigos epicuristas, deus era um mentor espiritual. Horácio é um eclético por excelência. Ora descobrimos laivos de epicurismo nele, já apresentam-se elementos estóicos; já, cínicos. Ele vê com indiferença a tradição religiosa, ou, entāo, assume uma postura de mera participação exterior do culto público. Hoje em dia, no meu modo de ver, ele não passaria de um ateu. Conforma-se com o fato de ser um mortal apenas, resignado com a transformação incessante e permanente pela qual as coisas se constroem e se dissolvem noutras coisas - o devenir - e ignorando o futuro. Na Ode III, 29, v. 29-32, fica-nos uma idéia bastante nitida a esse respeito:

"Prudens futuri temporis exitum caliginosa nocte premit deus ridetque, si mortalis ultra fas trepidat. .," 
(Um deus prudente encobre o desfecho do tempo futuro com uma noite tenebrosa, e ri se um mortal se inquieta além do justo).

O objeto da arte poética de Horácio sāo os conteúdos da vida humana, a arte do viver, o bem do Estado, a amizade. o amor e o vinho; na esteira de tudo, sobretudo do amor, segue a longa presença da morte. Também a eternidade da glória faz parte dos motivos simbólicos de uma realidade interior, na qual os limites subjetivos da poesia lírica se estendem à humanidade.

$\mathrm{Na}$ Ode III, 29 temos oportunidade de entrar em contato com as confidências horacianas. Parece um monólogo de advertência, mas o poeta nāo deixa de trazer à baila o nosso "memento" atual, quase cristão. Ele dá a conhecer aos amigos o seu estado fílosófico. Nesta confidência está talvez o verdadeiro epicurismo da ode, dominada de uma condenação do desejo, que tem coloração estóica. Mecenas está tão impregnado dos deveres para com o Estado, que chega a esquecer-se de ser feliz. $E$ preciso tomar alguma iniciativa. O presente é tudo, mas não passa de um resultado. Deus pode modificar o futuro que não nos pertence, consta em Epicuro, mas não o porvir da alma.

Na Ode IV, 7, na alegoria a Minos, Horácio diz que a morte não apaga os valores, mas apaga do homem também o ânimo:

"Cum semel occideris et de te splendida Minos fecerit arbitria,

non, Torquate, genus, non te facundia, non te restituet pietas;

infernis neque enim tenebris Diana pudicum liberat Hippolytum,

nec Lethaea valet Theseus abrumpere caro vincula Pirithoo". (v. 21-28).

(Quando uma vez morreres e Minos tiver dado a teu respeito suas sentenças esplêndidas, Torquato, nem tua linhagem, nem tua eloquiência, nem tua piedade te ressuscitarão. Pois nem Diana liberta das trevas infernais ao casto Hipolito, nem Teseu consegue quebrar as correntes do Lete para o seu caro Perítoo).

Sempre a morte batendo à porta do gênio poético de Horácio. Com a mudança das estações, ele nos adverte da brevidade da vida; apressemo-nos em aproveitar - melhor - em gozar a hora que nos escapa. A natureza se renova. 
A morte pode bater a nossa porta amanhã, e nós não veremos jamais a luz. Embora membro de uma família ilustre, Torquato também morrerá e seu nome será esquecido. Vã serả também sua eloqüência famosa de advogado.

Conquanto usando a idéia emprestada de Lucílio, que, por sua vez, a tomou aos gregos, Horácio tornou-se conhecidíssimo pelo seu "carpe diem"; tão conhecida ficou essa expressão, que adquiriu vida autônoma, independente do próprio poema. Ao abordar o "carpe diem", volta à tona a ansiosa temporalidade horaciana. A esse respeito, vale a pena citar J. PERRET: "Horácio se associa a uma família de inteligências para as quais o lugar autêntico do homem não é a continuidade de uma duração de tempo, com as ilusōes inerentes à memória e ao projeto, mas a singularidade dos instantes onde a nossa liberdade enfrenta o mun. do"3.

Na Ode XI, o poeta faz-nos a descrição de um quadro das superstições orientais, da crença na astrologia em Roma. As mulheres, sobretudo, estavam cada vez mais se ligando a isso. Horácio procura dissuadir a uma delas de indagar so. bre o futuro. Diz que nós não podemos decifrá-lo, pois seu conhecimento escapa a nossa capacidade. Em compensação, aconselha Leucônoe a usufruir os bens da vida, diariamente, sem contar muito com o amanhā. A ode é curta, mas de uma densidade extraordinária. Cito-lhe uma parte:

"Seu pluris hiemes seu tribuit Iuppiter ultimam, quae nunc oppositis debilitat pumicibus mare Tyrrhenum, sapias, vina liques et spatio brevi spem longam reseces. Dum loquimur, fugerit invida

aetas: carpe diem, quam minimum credula postero". (Od. I, 11).

(Quer Júpiter conceda muitos invernos, quer conceda como último este que enfraquece agora o mar Tirreno com penedos opostos, sê sábia, filtra teus vinhos e elimina uma esperança longa num espaço breve de tempo. Enquanto falamos, o tempo inve. joso pode ter fugido: aproveita o dia, o mínimo possivel crédula no seguinte).

Para Horácio, ser "sapiens" faz parte da essência do ho. mem, para que possa levar uma vida tranquiila, com liberdade. O temor, sobretudo da morte, tolhe-lhe essa tranquiilidade.

3 PERRET. J. Hotace. In: ORAzIO FLACCO, Quinto. Odi - Epodi. MJilano: BUR, 1985. p. 13. 
Esse motivo está presente em grande parte da obra horaciana, com nuances de acordo com os assuntos tratados. No Epodo 13 - verso 3 e seguintes - surge, no lugar de "carpe", "rapiamus", que exprime urgência e violência:

"rapiamus, amici, occasionem de die" (roubemos, amigos, a ocasiāo ao dia). Na Ode III, 8, v. 27, aparece "capio": "dona praesentis cape laetus horae". (toma alegre os dons da hora presente) .

Na Carta I, 11, v. 23 segs., encontramos o verbo "sumere":

"tu quamcumque deus tibi fortunaverit horam, grata sume manu neu dulcia differ in annum". (Tu, qualquer que seja a hora com que deus te afortunou, toma-a com mão agradecida e não adies as coisas doces para o futuro).

Ainda que os verbos citados sejam muito significativos, "carpo" é o mais novo de todos e o mais expressivo; ele envolve a conotação de um movimento dilacerante e progressivo entre as partes e o todo, tal qual acontece num gesto de descascar uma fruta. O todo é o tempo - "aetas" -; a parte é o dia - "dies", para ser desfrutado diariamente, sem contar com o amanhã.

Horácio é sempre atual, quer o leiamos diretamente, quer como que indiretamente, nos muitos escritores que the seguem a mesma linha de raciocínio. Sobressai-se, na abordagem do "carpe diem", o poeta português Fernando Pessoa. Ele teria sido a própria encarnação da consciência infeliz do homem. Sob o pseudônimo de Ricardo Reis, Pessoa criou odes pagãs e neoclássicas, no estilo de Horácio. Ricardo Reis pretende-se um epicurista horaciano e exprime-se só por símbolos e idéias gerais e consagradas. "O heterônimo Ricardo Reis exprime, contra as concepções meramente abstractas de sobrevivência 'post-mortem' ou de progresso humano, e em estilo que poderiamos designar de neo-arcádico, embora apresentando uma densidade de significado muito mais próxima do modelo horaciano, a antiga sabedoria epicurista egocêntrica que se reduz à estimativa e opção astuta entre dores e prazeres prováveis, a colher num mundo que tanto faz considerar dominado pelos fados inelutáveis como por um jogo de forças transcendentes ao nosso conhecimento" ".

4 LoURenco. Eduardo. Fermando Peseos revisitado: Lelturs estruturante do drama em cente. Lisbos: Moraes Editores. 1981. Dág. 50-31. 
Semelhança, ou até identidade, existe muita entre Horácio e Fernando Pessoa-Ricardo Reis. A mesma angústia obsessiva alimentada pela consciência de que estamos aqui apenas "ad transeundum". Isso pode ser inferido com seguran. ça da Ode:

Altivamente donos de nós-mesmos

Usemos a existência

Como a vila que os deuses nos concedem

Para esquecer o estio.

Não de outra forma mais apoquentada

Nos vale o esforço usarmos

A existência indecisa $e$ afluente

Fatal do rio escuro.

Como acima dos deuses o Destino

É calmo e inexorável,

Acima de nós-mesmos construamos

Um fado voluntário

Que quando nos oprima nós sejamos

Esse que nos oprime,

$\mathrm{E}$ quando entremos pela noite dentro

Por nosso pé entremos ${ }^{5}$.

A esse respeito ainda, fala-nos Eduardo LOURENÇO: "O sábio procede como se ignorasse 'a morte' (esse esquecimen. to activo da morte, acaso a única vitória sobre ela, é a matriz mesma da Ciência) mas no homem que se esquece, a morte não se deixa esquecer. Que fazer? Ou antes, que convém que sejamos para, 'conscientes', ser o que só em pura ou fingida inconsciência sāo "o bruto" e o "sábio"? Assumir a necessidade, transformá-la estoicamente em virtude, encerrar os próprios deuses na armadilha que nos ofereceram, ou onde eles mesmos estão presos. Em suma, outra saída não existe que a de aderir, esposar, extenuar a 'nossa infelicidade radical' por uma aceitação altiva e desprendida da nossa condição, não só perecivel, mas sem cessar em transe de perecer"'.

Percebemos uma real tentativa de seguir os passos dos escritores clássicos da Antiguiidade; "na sua perfeição idealmente de mármore inscrito, dialogando com ela e na verda. de digna dela, o que sobressai é um fundo de angústia moderna, como moderna sob cor antiga, é a resposta para a não-resposta de onde nasce e extravasa. Nós somos 'tempo'

Idem. Ibldem. p. 50

Idem. Ibldem. p. 51. 
e nada mais, nós somos como depois de Schopenhauer tantas vezes se repetiu, uma breve 'luz' irrompendo sem razão no seio de uma Vida desprovida dela e de novo reenviada à pura Noite? Pois se assim é, seja assim. Aceitemos o jogo e joguemo-lo que só nessa aceitaçāo voluntária 'o bem consiste'. E mesmo a única maneira de ascender ao que é comum a homens e deuses"

Constantemente, Horácio refere-se a uma força superior, que ele chama de "Fortuna", à qual se sujeita fatalisticamente. PESSOA-Ricardo Reis deixa transbordar sua consciência teogônica universal numa perspectiva muito semelhante à daquele:

Anjos ou deuses, sempre nós tivemos,

A visão perturbada de que acima

De nós e compelindo-nos

Agem outras presenças.

Como acima dos gados que há nos campos

O nosso esforço, que eles nāo compreendem,

Os coage e obriga

$E$ eles não nos percebem,

Nossa vontade e o nosso pensamento

São as mãos pelas quais outros nos guiam

Para onde eles querem

E nós não desejamos

Outro autor português que me parece chegar "ad limina" do mundo existencial proposto por Horácio é David MourãoFerreira. Muito representativo desse filão metafísico é o poema "Sextina III ou Canção do Próprio Canto:

Revela-se o destino em cada canto ora da cor do barro ora do cobre mas a hora mais crua do combate é a que nunca tem horário certo Dizei-me quem nos prende quem nos solta Dizei-me quem nos mata quem nos mente

Se a morte não engana a vida mente Avidamente a escuto neste canto Perguntareis A qual A que me solta ou à que dia a dia mais me cobre Mas nem consigo responaier ao certo tão confuso no fundo é o combate

7 Idem. Ibldem. D. 63-64.

8 PESSOA. Fernando. Odes de Ricardo Reis. Lisboa: Atiea, 1981. p. 54. (Obras Completas de Fernando Pessoa. Tomo rV. 
Poder dizer ao menos quem combate Poder dizer ao menos não mente

Saber quem está errado quem estä certo não é porém poder que tenha o canto pois o escudo de cobre que me cobre por vezes se transforma em seda solta

Contra o destino é ele quem me cobre seja embora o destino mais que certo Sempre a mentir só ele é que não mente Por me prender só ele é que me solta $\mathrm{E}$ que importa o desfecho do combate Que importa tudo o resto enquanto canto

Anda canção à solta neste canto Ilude quem te mente quem te cobre quem te der como certo este combates.

Analisando o poema, assim se expressa a professora Juril do Nascimento CAMPELO:

"Nesta canção, a argúcia do poeta se exercita na análise da impotência do homem perante o destino e a morte. A primeira estrofe constata que o ser humano é vítima de uma cadeia de fatos cuja lógica lhe escapa e cujo desfecho sempre o surpreende. Na segunda estrofe o poeta sugere a contínua oscilação da consciência na tentativa de compreender os dois fenômenos maiores: a vida e a morte. Ao contrário dos filósofos, o poeta não chega sequer a distinguir as fronteiras entre ambos. A terceira estrofe revela, nos três primeiros versos, a perplexidade de quem não encontra defesa nem mesmo nas razões éticas que fundamentam a moral. A partir do quarto verso o poeta passa a falar da poesia (canto), reconhecendo que também ela é importante frente às indagações metafísicas. As imagens respectivamente de "escudo de cobre" e "túnica de seda", claramente relacionadas com categorias mitológicas, estabelecem o sentido de dureza e fragilidade da palavra poética, e por contigiuidade, do poeta.

(...) A quinta estrofe é ainda a continuação ideológica da anterior: agora o poeta admite que mente. Sem aludir ao "fingimento poético" pessoano, isto é, à aceitação da men-

9 CAMPELO, Juril do Nascimento. A oficina órfica de David Mourāo Ferreira. Tese. Curitiba, 1986. p. 90-91. (Professor titular) do Betor de ciéncias Humanas, Letras e Artes, Universidade Federal do Paraná, 1986. 
tira como recurso estético, como recriação do real vivido, o poeta trata da mentira essencial, espécie de defesa contra as armadilhas do destino, recurso enfim que disfarça a fraqueza do ser"10.

Já disse que Horácio não se define bem em que corrente filosófica se encaixa. Ele é, na verdade, um eclético. Sua preocupação essencial é a de pôr em prática o "slogan" do "carpe diem": sem ater-se, propriamente, a principios sociais ou a dogmas morais deste ou daquele escritor, vai colhendo o que há de melhor em cada corrente filosófica. Nesse caso, ficamos confusos se pretendemos classificá-lo dentro de padrões doutrinários; ele é antitético, pois uma hora diz uma coisa, outra, já se contradiz. Gregos e latinos influenciaramno. Influenciou-o o grego Aristipo, para quem o futuro nāo nos pertence, a não ser em parte. Mais constante é a presença de Epicuro, que diz não ser o futuro inteiramente nos. so; por isso, não podemos esperar muito dele, tampouco desesperar. O futuro depende, em parte, apenas de nós.

Basta analisar a Ode III, 29, para concluir que Horácio, ao convidar Mecenas a descansar no campo, fugindo de suas obrigaçōes de ministro diligente e fiel, prega uma vida de menos apego às coisas materiais. $\mathrm{Na}$ verdade, ele propugna por um ideal de conduta dentro de um sincretismo religioso. Nesse poema ele propōe nāo exagerar na eficácia de nossos esforços, por causa dos segredos do futuro e da força da Fortuna. Está evidente a antítese: vida na cidade (Roma) $x$ vida no campo. Com delicadeza, sugere a Mecenas que se afaste da poluição de Roma:

Fastidiosam desere copiam et molem propinquam nubibus arduis, omitte mirari beatae

fumum et opes strepitumque Romae. (v. 9-12).

(Abandona a abundância enfadonha e o edifício próximo das nuvens elevadas; deixa de admirar a fumaça, as riquezas e o estrépito da ditosa Roma).

Para o cristianismo, Deus propõe e o homem dispōe. Para Horácio, cabe a Fortuna dispor dos bens materiais:

Fortuna saevo laeta negotio et

ludum insolentem ludere pertinax

transmutat incertos honores,

nunc mihi, nunc alii benigna. (v. 49-52). 
(A feliz Fortuna, em seu ofício cruel de, pertinaz, fazer um jogo insolente, transfere dignidades incertas, ora benigna a mim, ora, a outrem).

O cristianismo prega a conformidade e sujeição à vontade de Deus. Para Horácio, existe uma resignação fatalística e quase que mecânica:

Laudo manentem; si celeris quatit pinnas, resigno quae dedit et mea virtude me involvo probamque pauperiem sine dote quaero.

(Louvo (Fortuna) quando permanece; se bate asas céleres, restituo o que me deu e me envolvo em minha força e procuro uma pobreza proba e sem dote).

Horácio tem passagens que poderiam fazer parte de uma "Imitaçāo de Cristo". se convertidas para uma ascese cristã. Apesar de seu contexto social pagão. sua mensagem poderia ser de extraordinária utilidade para as pessoas que se dizem "religiosas", mas que. na prática, procuram mercadejar com Deus e seus santos. Qual eremita em seu retiro nas monta. nhas sabinas, o poeta latino diz que não pretende pactuar com votos com os deuses. como se pudéssemos comprá-los para que eles façam o que nós queremos:

Non est meum, si mugiat Africis malus procellis. ad miseras preces decurrere et votis pacisci. ne Cypriae Tyriaeque merces addant avaro divitias mari. (v. 57-60).

(Não é meu costume. se meu mastro uiva nas procelas áfricas. recorrer às míseras preces e pactuar com votos. para que as mercadorias de Chipre e de Tiro não acrescentem riquezas ao mar avarento).

Apesar de seu sincretismo religioso, evidencia-se que a pedra angular horaciana alicerca a "virtus". que se identifica com "aequus animus". isto é. a impassibilidade. a tranquililidade de espírito; só assim o homem consegue viver feliz. Se agir de maneira ímpia, ele será a causa de suas próprias desventuras. Diz que é inútil correr ao encalco dos bens da vida. é inútil preocupar-se das futilidades, conquistar honras e riquezas: a morte dá um fim a tudo. 
Na concepção epicurista, a adequação "homo/virtus" era conseguida pela procura da tranquiilidade da alma, enquanto que, para os estóicos, a "virtus" consistia em viver o momento presente, sem transferir as coisas para o futuro; eximir-se, portanto, de pensar no futuro.

A contemporaneidade de Horácio perpassa e extravasa suas obras. No dizer de SELLAR, "He is one of the few ancient writers who unite all the cultivated nations of modern times in a common admiration. They each seem to claim him as especially their own"11. Seu estudo exigiria um trabalho dantesco, que abrangesse todas as suas obras. Esta monografia pretendeu mostrar, de leve, que espirito filosófico - sobretudo no aspecto religioso e moral - se pode extrair das Odes horacianas. Foram feitas algumas incursōes em outras obras de Horácio para comprovar e ratificar os pontos de vista tirados das Odes. Com certeza, Horácio também se deixa trair pelo "Zeitgeist". Sua obra, por sua vez, vai ter reflexos mais ou menos profundos em literaturas posteriores, como procurei mostrar em leves pinceladas.

Apesar das limitações, parece-me ter ficado claro que Horácio tem um "corpus" de dados que permitem concluir por uma linha filosófica definida quanto à fugacidade do tempo, à inutilidade das paixōes, à despreocupação com as coisas passageiras. Ser filosófo, para ele, significa procurar a "virtus" na paz, no sossego, na "tranquillitas animi", pois quem nasceu feliz perderá essa felicidade se não tiver a paz de espirito. Mas, acima de tudo, significa dedicar-se, com tempo integral, ao "carpe diem", usufruir o tempo presente como se cada instante fosse o último de nossa vida. Para ele ainda, o extremo oposto ao presente é o futuro: um futuro não esperado mas temido, uma fuga ao porvir, que joga sobre o presente uma sombra de morte.

Horácio conseguiu, de fato, erigir seu monumento, um monumento realmente perene ("exegi monumentum aere perennius" - Odes III, 300), certamente mais duradouro do que previu o próprio poeta. Confirmou-se, igualmente, o seu famoso

non omnis moriar multaque pars mei vitabit Libitinam; usque ego postera crescam laude recens...

(não desaparecerei completamente, pois grande parte de mim evitará a morte; eu crescerei sempre no louvor futuro, como sendo novo).

11 GEILAR, W.Y. op. elt. p. 4. 
Sua mensagem continua perene nesta comédia da vida que cada um representa ou vive, numa perenidade não só maior que o próprio bronze, mas superior mesmo ao próprio ouro olímpico.

\section{REFERENGIAS BIBLIOGRAFICAS}

01 BIELER, Ludwig. Historia de la Literatura Romana. Madrid: Editorial Gredos, 1968. $329 \mathrm{p}$.

02 BRUN, Jean. El Estoicismo Trad. de Thomas Moro Simpson. Buenos Aires: Edit. Univ. de Buenos Aires, 1977.

04 CAMPELO, Juril do Nascimento. A oficina órfica de David MourāoFerreira. Curitiba, 1986. 177p. Tese (Professor titular). Setor de Ciências Humanas, Letras e Artes, Universidade Federal do Paraná, 1986.

04 CETRANGOLO, Enzio. Breve storia della Letteratura Latina. Roma: Editori Riuniti, 1983. 264 p.

05 DOURADO, Mecenas. Mecenas ou o suborno da inteligência. Rio de Janeiro: Edições do Povo Ltda., 1947. 237 p.

06 GIORDANI, Mário Curtis. História de Roma. 3.ed. Petrópolis: Vo. zes, $1972.398 \mathrm{p}$.

07 GRIMAL, Pierre. La Littérature Latine. Paris: Presse Universitajres de France, 1965. $127 \mathrm{p}$.

08 HORACE. Oeuvres complètes; Odes et Épodes. Traduction par François Richard. 294 p. Paris: Garnier Frères, 1950. Tome I.

09 HORACIO. Obras completas; Odes, Epodos, carme secular, Sátiras e Epistolas. Tradução de Elpino Duriense "et al". 318 p. São Paulo: Edições Cultura, 1941.

10 LOURENÇO, Eduardo. Fernando Pessoa revisitado; leitura estruturante do drama em gente. Lisboa: Moraes Editores, 1981. $197 \mathrm{p}$.

11 ORAZIO FLACCO, Quinto. Odi e Epodi. Milano: BUR, 1985. 553 p.

12 ORAZIO. Satire. Milano: BUR, 1981. $337 \mathrm{p}$.

13 PESSOA, Fernando. Odes de Ricardo Reis. Lisboa: Atica, 1981. 204 p. (Obras Completas de Fernando Pessoa. Tomo IV).

14 PLESSIS, F.; LEJAY, P. Oeuvres d'Horace. Paris: Hachette, 1948. $642 \mathrm{p}$.

15 SARAIVA, António José; LOPES, Óscar. História da Literatura Portuguesa. 2.ed. Porto: Porto Editora, s/d. $966 \mathrm{p}$.

16 SELLAR, W.Y. The Roman poets of the Augustan age; Horace and the elegiac poets. Oxford: At the Clarendon Press, 1924. $360 \mathrm{p}$.

17 TERzaGHI, Nicola. Per la storia della satira. Torino: Edizioni de "L’Erma", s/d. 79 p.

18 TRINGALI, Dante. Horácio, inventor do amor e da mulher na poesla ocidental. Suplemento Literário "Minas Gerais", Belo Horizonte: Órgāo Of. dos Poderes do Est., ano XXII, n. ${ }^{\circ} 1058$, 24 jan. 1987. 